\title{
Characteristics and distribution of dental anomalies in a Brazilian cleft population
}

\author{
Características e distribuição de anomalias dentárias em uma \\ população brasileira de portadores de fissuras lábio-palatais
}

\begin{abstract}
Purpose: To determine the prevalence of dental anomalies in 200 cleft patients undergoing orthodontic treatment at the Cleft Rehabilitation Center (CERLAP) of the Pontifical Catholic University of Rio Grande do Sul.

Methods: Data regarding patient age, race, gender, cleft type (lip and alveolus, complete lip and palate, or cleft palate), affected side (unilateral or bilateral), agenesis and supernumerary teeth in both arches were assessed from orthodontic records comprised by panoramic, cephalometric, occlusal, and periapical radiographs, study models, intra- and extraoral photographs, obtained at the beginning of the treatment, providing needed information to make an accurate diagnosis of dental anomalies. The collected data were registered in spreadsheets.

Results: The mean patient age was 13.5 years old; $86 \%$ were white; and $57 \%$ male. Complete cleft lip and palate was found at a higher frequency (83\%); the left side was most affected $(48.5 \%)$. Agenesis were found in $66.5 \%$ of patients. Maxillary lateral incisors were the most absent teeth $(78.5 \%)$. Supernumerary teeth were found in $35.5 \%$ of patients.

Conclusion: Male individuals demonstrated a greater tendency to present clefts and manifest both agenesis and supernumerary teeth. Complete cleft lip and palate prevailed, and the left maxillary lateral incisor was the most absent tooth. Supernumeraries were located distally to the cleft.
\end{abstract}

Key words: Cleft palate; anodontia; tooth, supernumerary; epidemiology

\section{Resumo}

Objetivos: Determinar a prevalência de anomalias dentárias em 200 pacientes com fissura sob tratamento ortodôntico no Centro de Reabilitação Lábio-Palatal (CERLAP) da Pontifícia Universidade Católica do Rio Grande do Sul (PUCRS).

Metodologia: Os dados referentes à idade, raça, gênero, tipo de fissura (pré, trans ou pósforame incisivo), lado afetado (uni ou bilateral), agenesias e supranumerários em ambas arcadas foram avaliados a partir da documentação ortodôntica constituída por radiografias panorâmicas, cefalométricas, oclusais e periapicais, modelos de estudo e fotografias intra e extrabucais obtidas no início do tratamento, fornecendo informações necessárias para diagnóstico de anomalias dentárias. Os dados coletados foram registrados em planilhas.

Resultados: A média de idade dos pacientes foi de 13.5 anos; $86 \%$ eram brancos; e $57 \%$ eram meninos. Fissuras transforame incisivo demonstraram-se mais frequentes (83\%); o lado esquerdo foi mais afetado (48.5\%). Agenesias foram encontradas em $66.5 \%$ dos pacientes. Incisivos laterais superiores foram os dentes mais ausentes (78.5\%). Supranumerários foram encontrados em $35.5 \%$ dos pacientes.

Conclusão: Meninos demonstraram maior tendência a apresentar fissuras e a manifestar agenesias dentárias e supranumerários. As fissuras completas de lábio e palato prevaleceram e os incisivos laterais superiores foram os dentes mais ausentes. Os supranumerários localizaram-se distalmente à fissura na maioria dos casos.

Palavras-chave: Fissura palatina; agenesia dentária; dente supranumerário; epidemiologia

\author{
Luciane Macedo de Menezesa \\ Susana Maria Deon Rizzatto a \\ Fabiane Azeredo b \\ Diogo Antunes Vargas ${ }^{b}$
}

\begin{abstract}
- Department of Orthodontics, Pontifical Catholic University of Rio Grande do Sul, Porto Alegre, RS, Brazil

${ }^{b}$ Graduate program in Orthodontics, Pontifical Catholic University of Rio Grande do Sul, Porto Alegre, RS, Brazil
\end{abstract}

\author{
Correspondence: \\ Luciane Macedo de Menezes \\ Av. Ipiranga, 6681 - Prédio 6 \\ Porto Alegre, RS - Brasil \\ 90619-900 \\ E-mail: luciane@portoweb.com.br
}

Received: December 7, 2009

Accepted: March 14, 2010

Conflict of Interest Statement: The authors state that there are no financial and personal conflicts of interest that could have inappropriately influenced their work.

Copyright: (C) 2010 Menezes et al.; licensee EDIPUCRS. This is an Open Access article distributed under the terms of the Creative Commons AttributionNoncommercial-No Derivative Works 3.0 Unported License. 


\section{Introduction}

Cleft lip and/or palate is one of the most common birth defects, and is certainly the most visible deformity, associated with substantial clinical and psychosocial impact (1). These deformities may occur alone (nonsyndromic) or as one of multiple congenital malformations (syndromic) (2). The etiology is complex, involving genetic and environmental factors $(3,4)$. Multiple studies have shown a number of genes may be involved $(2,5)$, as well as environmental or lifestyle factors, such as parental drug use or smoking $(2,6)$ and folic acid deficiency $(2,7)$.

The prevalence of cleft lip and/or palate varies with respect to racial and ethnic background $(3,8)$, geographic origin $(3,9)$, and socio-economic status $(3,10)$. In some populations, the prevalence is as high as 1:500 births; in others, it may be as low as 1:2500 births $(10,3)$. Recent data showed that the prevalence of orofacial clefts in live newborns from 1998 to 2002, in Brazilian state capitals, was 0.36:1000 in the five year period, and there was a proportion of this occurrence in 1.6 men for every female (11). Unilateral cleft lip and palate is the most frequent cleft, representing $33 \%$ of such deformities (12); and the left side is most commonly affected (13).

Congenital developmental dental anomalies are found to occur at a markedly increased frequency in children affected with cleft lip and/or palate compared to the general population (14). Dental characteristics determined by the development of the alveolar process in the region of the cleft $(14,15)$ include anomalies of number (absence or supernumerary), form, size, time of formation and/or eruption, direction of tooth growth, and formation and mineralization of enamel (14). The degree and frequency of tooth anomalies seems to be related to the severity of the cleft or cleft type $(16,15)$.

The permanent maxillary lateral incisors have been specifically studied in this population because of their position $(17,18)$ as well as esthetic and functional roles $(4)$. The congenital absence of these teeth is the most common finding in children with cleft lip and/or palate $(18,19)$. This is followed in frequency by supernumerary teeth in the cleft region, which the literature confirms as the second most common anomaly $(18,20)$.

The purpose of the study was to determine the general characteristics and prevalence of dental anomalies in a specific group of Brazilian patients with cleft lip and alveolus (CLA), cleft lip and palate (CLP), or cleft palate (CP). Information presented in the orthodontic records, along with panoramic, occlusal, and periapical radiographs, photographs, and study models from the initial stage of the orthodontic treatment, was used to examine patient age, race, sex, cleft type, affected side, tooth agenesis, and presence of supernumerary teeth.

\section{Methodology}

To conduct this study were analyzed dental records of 200 patients from a cleft population at the Cleft Rehabilitation Center (CERLAP) that is characterized by offering multidisciplinary treatment at the cleft patients provided by professionals of different Health Sciences including Dentistry, Psychology and Medicine, and it is based at the Dental School of the Pontifical Catholic University of Rio Grande do Sul (PUCRS), in Porto Alegre, RS, in the south region of Brazil. This sample represented, at the moment of this study, the totality of the orthodontic cases concluded or in treatment at the CERLAP including all patients with initial orthodontic records. Syndromic individuals or that with incomplete or absent documentation at the start of the orthodontic treatment were excluded.

Each clinical file contained information on the procedures to which each patient had been submitted. The orthodontic records consisted by intra- and extraoral photographs, dental casts, and periapical, occlusal, lateral cephalometric and panoramic radiographs that had been obtained at the beginning of treatment. This information was used to collect data regarding patient age, race, gender, cleft type (CLA, CLP or CP), affected side (right, left or bilateral), tooth agenesis and presence of supernumerary teeth in upper and lower arches providing needed information to make an accurate diagnosis of dental anomalies. No clinical examinations were performed in the individuals. The collected data was recorded in standardized spreadsheets and analyzed for possible association using Fisher Exact test.

\section{Results}

\section{General characteristics}

Two hundred patients with cleft lip and/or palate were included in the study group: 86 were girls and 114 boys. The average age of the individuals was 13.5 years old, with a standard deviation of 5.6 years of age. In terms of race, it was observed that $86 \%$ of the patients were white and $14 \%$ were black. Males were more frequently affected by clefts than females (Table 1 and 2). When the type of malformation was considered, complete cleft lip and palate (CLP) was found with the highest frequency $(83 \%)$; this was followed by cleft lip and alveolus (CLA) (14.5\%) and cleft palate (CP) $(2.5 \%)$.
Table 1. Patient distribution in relation to gender and cleft type.

\begin{tabular}{|c|c|c|c|c|}
\hline \multirow[b]{2}{*}{ Gender } & \multicolumn{3}{|c|}{ Cleft type } & \multirow[b]{2}{*}{ Total } \\
\hline & $\begin{array}{l}\text { Cleft Lip and } \\
\text { Alveolus (CLA) }\end{array}$ & $\begin{array}{l}\text { Cleft Lip and } \\
\text { Palate (CLP) }\end{array}$ & Cleft Palate (CP) & \\
\hline Female & $13(44.8 \%)$ & 70 (42.2\%) & $3(60.0 \%)$ & $86(43.0 \%)$ \\
\hline Male & $16(55.2 \%)$ & $96(57.8 \%)$ & $2(40.0 \%)$ & 114 (57.0\%) \\
\hline Total & 29 (100\%) & $166(100 \%)$ & $5(100 \%)$ & 200 (100\%) \\
\hline
\end{tabular}


In the comparative analysis relating patient gender to cleft type, males presented a greater frequency of clefts involving the lip and palate. For cases involving isolated malformations of the palate, a greater frequency was noted for the female gender. The results obtained using the Fisher Exact Test revealed that there was no significant association among the listed variables $(x=0.774 ; p=0.756)$ (Table 1$)$.

The side most commonly affected by clefts was the left, representing $48.5 \%$ of the total cases analyzed. Bilateral clefts were observed in $28.5 \%$ of patients, followed by unilateral clefts on the right side (19.5\%) and isolated cleft palate $(3.5 \%)$.

\section{Frequency of tooth agenesis}

Congenital dental absences were noted in 133 individuals of which $59.4 \%$ were male. Roughly $68.5 \%$ of the agenesis was located in the second quadrant of the dental arch; others $52 \%$ in the first, $12.5 \%$ in the fourth and $12 \%$ in the third quadrant. Maxillary incisors, followed by the maxillary premolars, were the most frequent congenitally missing teeth (Table 3). The lateral incisors had the largest agenesis prevalence: they were absent on the left side in $50 \%$ and on the right side in $28.5 \%$ of individuals.

\section{Frequency and distribution pattern of the supernumerary teeth}

In total, $35.5 \%$ of the patients manifested at least one supernumerary tooth that was either erupted or impacted (Table 4). Among these individuals, $67.6 \%(n=48)$ were boys and $32.4 \%(n=23)$ were girls. In the majority of these cases, the patients presented only one extra tooth (Table 4). The average number of supernumerary teeth was 1.3 and the standard deviation was 0.59 . The distribution pattern of these teeth varied. Cases were classified and identified in accordance to the number of supernumerary teeth and their location (i.e., mesial, distal, or on both sides) in relation to the alveolar cleft (Fig. 1). A unilateral cleft presenting one supernumerary tooth situated distal to the cleft was the
Table 2. Patient distribution with or without congenital dental absence, according to gender and total number of patients.

\begin{tabular}{lcccccc}
\hline \multirow{2}{*}{ Gender } & \multicolumn{2}{c}{ With Agenesis } & \multicolumn{2}{c}{ Without Agenesis } & \multicolumn{2}{c}{ Total } \\
\cline { 2 - 7 } & $\mathrm{N}^{\circ}$ & $\%$ & $\mathrm{~N}^{\circ}$ & $\%$ & $\mathrm{~N}^{\circ}$ & $\%$ \\
\hline Female & 54 & 62.8 & 32 & 37.2 & 86 & 43 \\
Male & 79 & 69.3 & 35 & 30.7 & 114 & 57 \\
Total & 133 & 66.5 & 67 & 33.5 & 2000 & 100 \\
\hline
\end{tabular}

Table 3. Frequency of agenesis by group of teeth.

\begin{tabular}{lcc}
\hline \multicolumn{1}{c}{ Group of teeth } & Number of agenesis & $\%$ \\
\hline Upper Incisors Lower & 179 & 179 \\
Incisors & 15 & 7.5 \\
Upper Canines & 6 & 3.0 \\
Lower Canines & 1 & 0.5 \\
Upper Premolars & 34 & 17.0 \\
Lower Premolars & 11 & 5.5 \\
Upper Molars & 22 & 11.0 \\
Lower Molars & 22 & 11.0 \\
Total of patients & 200 & \\
\hline
\end{tabular}

* Teeth of unequal groups can be absent simultaneously.

Table 4. Quantity and frequency of extra teeth among patients with supernumeraries.

\begin{tabular}{ccc}
\hline $\begin{array}{c}\text { Supernumerary } \\
\text { ( } \mathbf{N}^{\circ} \text { of teeth) }\end{array}$ & $\mathbf{N}^{\circ}$ individuals & $\%$ \\
\hline 1 & 52 & 73.3 \\
2 & 16 & 22.5 \\
3 & 2 & 2.8 \\
4 & 1 & 1.4 \\
Total & 71 & 100.0 \\
\hline
\end{tabular}

most frequent pattern (pattern J) in both genders and overall (Fig. 1 and Table 5). Patterns D and C, which revealed the preference of supernumerary teeth for the distal portion of the cleft, were found to be the most frequent in patients who carried bilateral clefts (Fig. 1 and Table 5).

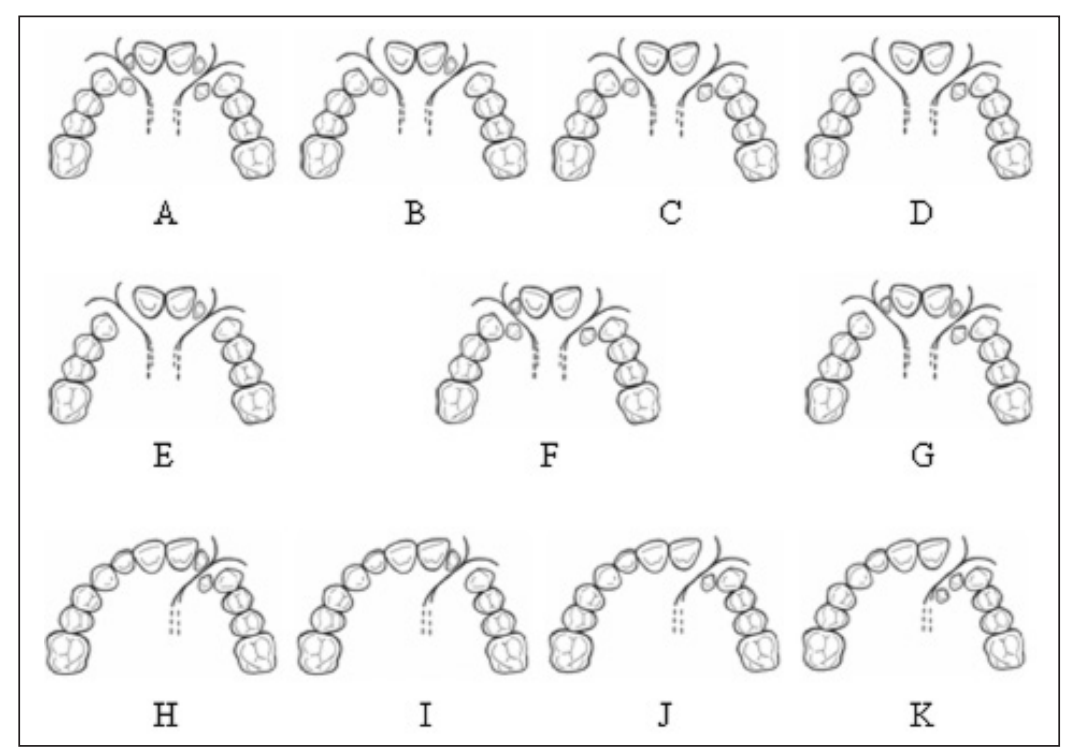

Fig. 1. Eleven patterns of supernumerary distribution in unilateral and bilateral clefts, identified by number of teeth and its location, by mesial, distal or both sides of the cleft (Adapted from Tsai et al. [20]). 
Table 5. Distribution pattern of supernumerary related to gender.

\begin{tabular}{|c|c|c|c|c|c|c|c|c|c|c|c|c|}
\hline \multirow{3}{*}{ Gender } & \multicolumn{12}{|c|}{ Pattern } \\
\hline & \multicolumn{7}{|c|}{ Bilateral Clefts* } & \multicolumn{4}{|c|}{ Unilateral Clefts** } & \multirow{2}{*}{ Total } \\
\hline & A & B & C & $D$ & $E$ & $\mathrm{~F}$ & G & $\mathrm{H}$ & I & $\mathrm{J}$ & $\mathrm{K}$ & \\
\hline Female & 0 & 0 & 3 & 2 & 0 & 1 & 0 & 2 & 1 & 14 & 0 & 23 \\
\hline Male & 1 & 3 & 3 & 6 & 1 & 0 & 1 & 3 & 1 & 27 & 2 & 48 \\
\hline Total & 1 & 3 & 6 & 8 & 1 & 1 & 1 & 5 & 2 & 41 & 2 & 71 \\
\hline
\end{tabular}

* Bilateral clefts: (A) one supernumerary tooth mesially and one distally to the cleft on right and left sides of the arch; (B) one supernumerary tooth mesially and one distally to the cleft in opposite sides of the arch; (C) one supernumerary tooth located distally to the cleft in each side of the arch; (D) one supernumerary tooth located distally to the cleft in one of the sides; (E) one supernumerary tooth located mesially to the cleft; $(F)$ one supernumerary tooth mesially and one distally to the cleft in a same side of the arch and in the opposite side the supernumerary is located distally to the cleft; (G) one supernumerary tooth mesially and one distally to the cleft in a same side of the arch and in the opposite side the supernumerary is located mesially to the cleft.

** Unilateral clefts: $(H)$ one supernumerary tooth mesially and one distally to the cleft; (I) one supernumerary tooth mesially to the cleft; $(\mathrm{J})$ one supernumerary tooth distally to the cleft; $(\mathrm{K})$ two supernumerary tooth distally to the cleft.

\section{Discussion}

Cleft lip and palate are known to occur more frequently in male individuals, whereas isolated cleft palate is more common in females $(4,13,15)$. The masculine gender presents a remarkable predominance of complete cleft lip and palate, unilateral or bilateral, which occur in between $59 \%$ and $64 \%$ of the cases, respectively (13). Baek et al. (15) showed that the ratio of males to females was $1.88: 1$ in cases of lip and alveolus compromise; this ratio was 2.49:1 for the cleft lip and palate in a Korean patient group. In the present study, the male population was also shown to be predominant and comprised $57 \%$ of the analyzed group; cleft lip and palate was the most frequent anomaly $(n=83 \%)$. The rate of boys to girls was 1.23:1 for cleft lip and alveolus, 1.37:1 for cleft lip and palate, and 1:1.5 for cleft palate. These findings agree with the data found in the literature that describe a greater tendency for male patients to present clefts. With regard to race, $86 \%$ of the patients were white; in these patients, the left side was the most frequently affected $(\mathrm{n}=48.5 \%)$. In a similar study with Brazilian individuals, Furlaneto and Pretto (21) found that: 1) white patients were most frequently affected by clefts $(n=96.3 \%), 2$ ) members of the male gender were more frequently affected $(n=54.6 \%)$, 3 ) clefts comprising lip and palate were the most frequent anomaly ( $\mathrm{n}=68.21 \%)$, and 4 ) anomalies showed a left-side preference $(\mathrm{n}=59.0 \%)$.

A large variety of dental anomalies can be found in cleft patients. These include disturbances of dental development on the cleft side, hyperdontia, hypodontia, anomalies in the size and shape of teeth, alterations of the enamel structure of the teeth involved in the cleft, and possible ectopic eruption of the canines on the affected side $(19,22,23)$. Both the deciduous and permanent dentitions are affected, but these anomalies occur at a considerably higher rate in the permanent dentition (14).

Bohn (19) reported that the prevalence of agenesis in the primary dentition of patients with clefts was $14.3 \%$, whereas this value in permanent teeth was $45.5 \%$. In an Israeli study (23) that evaluated 179 cleft individuals, congenitally missing teeth were noted in $67.6 \%$ of the patients. The most frequently absent teeth, excluding the third molars, were the permanent maxillary lateral incisors in the cleft region and the second premolars outside the cleft area $(14,18,24)$. In the present study, the 200 patients analyzed had either permanent or mixed dentition, and $66.5 \%$ of the cases showed at least one congenitally missing tooth. Maxillary lateral incisors were the most frequently missing tooth, with absences on the left side in $50 \%$ and on the right side in $28.5 \%$ of patients. This data relates directly to the fact that most of the patients had clefts on the left side $(48.5 \%)$ or bilateral clefts $(28.5 \%)$. In accordance with the available literature, the maxillary premolars had the highest incidence of agenesis (17\%) outside on the cleft area.

The hypothesis supported by Tsai et al. (20) proposes that cleft patients with a severe deficiency of mesenchymal mass develop agenesis of the lateral incisor; in contrast, subjects with a less severe deficiency have a lateral incisor on the distal or mesial side that may be accompanied by a supernumerary tooth, depending on the location of the odontogenic mass (i.e., in one or both processes). According to the analysis performed in this study, supernumerary teeth preferentially manifest distal to the cleft region.

As reported by Larson et al. (22), the prevalence rates of supernumerary teeth in children with cleft lip palate and cleft lip and alveolus were $27 \%$ and $58 \%$, respectively. However, supernumerary teeth in the current epidemiologic study predominated among clefts involving the lip and palate, which accounted for the majority of cases evaluated $(83 \%)$.

\section{Conclusions}

The analysis from our results and discussion demonstrate that the white race was more frequently affected $(86 \%$ of patients). Cleft lip and palate occur with a greater frequency on the left side, with the unilateral cleft lip and palate type being the most common. Males presented greater susceptibility to maxillary fusion defects, as well as a greater tendency to manifest congenitally missing or supernumerary teeth. The left maxillary lateral incisors predominated as the most frequently absent teeth. Supernumeraries, when present, were preferentially located distally with respect to the cleft. 


\section{References}

1. Aljohar A, Ravichandran K, Subhani S. Pattern of cleft lip and palate in hospital based population in Saudi Arabia: retrospective study. Cleft Palate Craniofac J 2008;45:592-6.

2. Jaruratanasirikul S, Chichareon V, Pattanapreechawong N, Sangsupavanich P. Cleft lip and/or palate: 10 years experience at a pediatric cleft center in southern Thailand. Cleft Palate Craniofac J 2008;45:597-602.

3. Slayton RL, Williams L, Murray JC, Wheeler JJ, Lidral AC, Nishimura CJ. Genetic association studies of cleft lip and/or palate with hypodontia outside the cleft region. Cleft Palate Craniofac J 2003;40:274-9

4. Kim NY, Baek SH. Cleft sidedness and congenitally missing or malformed permanent maxillary lateral incisors in Korean patients with unilateral cleft lip and alveolus or unilateral cleft lip and palate. Am J Orthod Dentofacial Orthop 2006; 130:752-8.

5. Spritz RA. The genetics and epigenetics of orofacial clefts. Curr Opin Pediatr 2001;13:556-60

6. Honein MA, Rasmussen SA, Reefhuis J, Romitti PA, Lammer EJ, Sun L, Correa A. Maternal smoking and environmental tobacco smoke exposure and the risk of orofacial clefts. Epidemiology 2007; 18:226-33

7. van Rooii IA, Vermeii-Keers C, Kluiitmans LA, Ocké MC, Zielhuis GA, Goorhuis-Brouwer SM, van der Biezen JJ, Kuiipers-Jagtman AM, Steegers-Theunissen RP. Does the interaction between maternal folate intake and the methylenetetrahydrofolate reductase polymorphisms affect the risk of cleft lip with or without cleft palate? Am J Epidemiol 2003; 157:583-91.

8. Croen LA, Shaw GM, Wasserman CR, Tolarová MM. Racial and ethnic variations in the prevalence of orofacial clefts in California, 1983-1992. Am J Med Genet 1998;79:42-7.

9. Vanderas AP. Incidence of cleft lip, cleft palate, and cleft lip and palate among races: a review. Cleft Palate J 1987;24:216-25.

10. Schutte BC, Murray JC. The many faces and factors of orofacial clefts. Hum Mol Genet 1999;8:1853-9.

11. Rodrigues K, Sena MP, Roncalli AG, Ferreira MA. Prevalence of orofacial clefts and social factors in Brazil. Braz Oral Res $2009 ; 23: 38-42$
12. Silva Filho OG, Ramos AL, Abdo RC. The influence of unilateral cleft lip and palate on maxillary dental arch morphology. Angle Orthod 1992;62:283-90.

13. Freitas JA, Dalben GS, Santamaria Jr M, Freitas PZ. Current data on the characterization of oral clefts in Brazil. Braz Oral Res 2004; 18:128-33.

14. Shapira $Y$, Lubit E, Kuftinec MM. Congenitally missing second premolars in cleft lip and cleft palate children. Am J Orthod Dentofacial Orthop 1999;15:396-400.

15. Baek SH, Kim NY. Congenital missing permanent teeth in Korean unilateral cleft lip and alveolus and unilateral cleft lip and palate patients. Angle Orthod 2007;77:88-93.

16. Baek SH, Moon HS, Yang WS. Cleft type and Angle's classification of malocclusion in Korean cleft patients. Eur J Orthod 2002;24:647-53.

17. Ribeiro LL, Neves LT, Costa B, Gomide MR. Dental development of permanent lateral incisor in complete unilateral cleft lip and palate. Cleft Palate Craniofac J 2002;39:193-6.

18. Ribeiro LL, Neves LT, Costa B, Gomide MR. Dental anomalies of the permanent lateral incisors and prevalence of hypodontia outside the cleft area in complete unilateral cleft lip and palate. Cleft Palate Craniofac J 2003;40:172-5.

19. Boehn A. Dental anomalies in harelip and cleft palate. Acta Odontol Scand 1963;21:1-109.

20. Tsai TP, Huang CS, Huang CC, See LC. Distribution patterns of primary and permanent dentition in children with unilateral complete cleft lip and palate. Cleft Palate Craniofac J 1998;35:154-60.

21. Furlaneto EC, Pretto SM. Epidemiological study of the patients from the center for facial abnormalities of Catholic University of Rio Grande do Sul. Rev Odonto Ciênc 2000;15:39-56.

22. Larson M, Hellquist $R$, Jakobsson OP. Dental abnormalities and ectopic eruption in patients with isolated cleft palate. Scand J Plast Reconstr Surg Hand Surg 1998;32:203-12.

23. Aizenbud D, Camasuvi S, Peled M, Brin I. Congenitally missing teeth in the Israeli cleft population. CLEFT PALATE CRANIOFAC 2005;42:314-7.

24. OLIN WH. Dental anomalies in cleft lip and palate patients. Angle Orthod 1964;34:119-23 